\title{
Promoters effectiveness in the improvement in iron and zinc absorption from the rice and bean
}

\author{
Larissa Catelli Rocha TORRES ${ }^{1 *}$ (D), José Eduardo Pedroso Gomes do AMARAL ${ }^{1}$, \\ Solange Guidolin Canniatti-Brazaca ${ }^{1}$
}

\begin{abstract}
Iron and zinc are essential micronutrients for the organism functioning and their lack can result in prejudices to human health. The information about the presence of minerals in the diet are normally referred to its total concentrations, however these values do not reproduce the fraction that might be bioaccessible for the human body. The objective of this study was to evaluate if the promoters increase the iron and zinc bioaccessibility in a rice-and-bean mix. For this, four treatments were elaborated, all containing rice and bean and varied between each other regarding the promoters added to this mix. Ascorbic acid and cysteine were the promoters chosen to evaluate the influence in the iron and zinc absorption. For this purpose, the tomato was chosen to act as ascorbic acid source and garlic and onion were chosen to act as cysteine source. The treatments with tomato presented a higher rate of iron, significantly differing from those without tomato in their composition. Treatment 4 was the one which provided the highest bioaccessibility for iron and was the only one that differed from the others. About zinc, there was no significant difference between the treatments regarding the total rate as well as the bioaccessibility.
\end{abstract}

Keywords: Caco-2; minerals; legumes; cereals; promoters.

Practical Application: Combination of promoters benefits the absorption of minerals.

\section{Introduction}

Rice and bean are a classic example of protein quality synergism between cereals and legumes, once both contain essential amino acids. An adequate proportion of cereals and legumes in a meal can present, from the protein point of view, a nutritional value equivalent to those presented by animal proteins (Cozzolino, 2012).

Among the legumes, bean is the one which presents the highest mineral rate, being an important source of iron, zinc, copper, phosphorus, and aluminium (Shimelis \& Rakshit, 2005). Besides that, beans are great sources of folic acid, tocopherols, thiamine, riboflavin, niacin, biotin, and pyridoxine (Hayat et al., 2014), also presenting elevated rates of lysins and complex carbohydrates. But it presents deficiency of sulphurated amino acids such as methionine and cysteine, both essential in feeding (Moura \& Canniatti-Brazaca, 2006).

Rice, for its turn, is the most consumed feeding culture in the world (Fitzgerald et al., 2009; He et al., 2013), providing $21 \%$ of the energy and $15 \%$ of the daily necessary proteins (Depar et al., 2011; Rehman et al., 2012). It is classified as the cereal which present the highest digestibility rate besides a good biological value (59-70\%) and elevated protein efficiency, for it presents good percentage of sulphurated amino acids such as methionine and cysteine (Minguita et al., 2015). The polished rice is poor in micronutrients like iron and zinc (Bouis \& Welch, 2010; Rehman et al., 2012).
Adequate levels of minerals are important for the organism's good functioning, based on the fact that they perform a great amount of metabolic functions. They are elements that must be provided to the human body by feeding (Khouzam et al., 2011). The information about minerals in the diet are normally referred to its total concentrations. However, these values do not reproduce the fraction that may be bioaccessible for the human body, that is, what is being released from the matrix being accessible in the gastrointestinal tract.

Nutritionally, bioaccessibility is defined as the fraction or quantity of the referred compound that is released from the food matrix during the gastrointestinal digestion and became available for being absorbed by the intestine (Jacob et al., 2012); while bioavailability is the fraction of a given food that the body can use and therefore is a question of nutritional efficiency that involves many process such as absorption, distribution, metabolism, and elimination phases (Rein et al., 2013) The bioaccessible fraction is influenced by the elements' chemical forms, by the behavior of organometallic species and complexes in the gastrointestinal tract and by the interactions with the food matrix (Khouzam et al., 2011).

Normally, bioaccessibility studies are conducted in vitro and are useful for evaluating possible interactions between nutrients and the many factors that can affect digestion and, consequently, the release of the nutrient by the matrix (Etcheverry et al., 2012). 
The digestion with enzymes along with the Caco-2 cellular model is a validated in vitro method which simulates the gastrointestinal digestion and the absorption in the food matrix (Vaz-Tostes et al., 2016). The iron absorption found in vegetables is considerably influenced by the solubility and interaction with other meal components, which can promote it or inhibit it (Institute of Medicine, 2006). The ascorbic acid acts as promoter because it potentializes the iron absorption, keeping it in the form of soluble chelate in the small intestine. Interactions allow the continuous electrons exchange and the consequent change of the state of oxidation of the iron from ferric ion to ferrous ion, then being possible to be captured by the erythrocytes.

Besides ascorbic acid, another promoter related to minerals absorption is cysteine, a sulphurated amino acid. Amino acids can increase the bioavailability removing the chelated zinc from dietetic constituents of linkage to zinc, like phytic acid. Evidence of this action was presented in studies of zinc absorption in fishes, in which the beneficial effects of the zinc addition as a chelated amino acid were higher in diets that contained high levels of phytic acid (Paripatananont \& Lovell, 1995). This increase in bioavailability can be obtained in two ways: amino acids can act in order to transport zinc of dietetic constituents with low linkage affinity to the mineral element, taking it to surfaces with more affinity (Ackland \& McArdle, 1990; Bobilya et al., 2013; Wapnir et al., 1985); or the formation of a zinc chelate amino acid can create a substrate for the transport through the epithelial surface (Wapnir et al., 1983).

Just like the existence of compounds capable of increasing the mineral absorption, there are also those which inhibit the absorption and can be called inhibitors or antinutrients. The dietetic factor that inhibit the bioavailability of the trace elements act in the solubility of these elements, reducing its absorption once they do not transfer the mineral element for the intestinal mucosa receptors (Clydesdale et al., 1991). Given that, it is essential to have a balanced diet which provides all the nutrients that the organism needs. However, we must consider that part of what we eat is not accessible. Thus, investing in strategies that increase the bioavailability of these micronutrients can be a good option of improvement.

In this context, the objective of this study was to add food containing promoters to the classic rice-and-bean mix in order to verify if there was difference regarding the iron and zinc bioaccessibility. The chosen promoters were ascorbic acid (with tomato as source) and cysteine (with garlic and onion as source). Four treatments were elaborated, being: $\mathrm{T} 1$ - rice and bean; T2 - rice, bean and tomato; T3 - rice, bean, garlic, and onion; T4: rice, bean, garlic, onion, and tomato.

\section{Material and methods}

\subsection{Material}

The grains of common bean (Phaseolus vulgaris) were donated by the Embrapa Rice and Beans and the chosen cultivar was BRS Pontal, from the carioca commercial group. The polished white rice, long thin class (Oriza sativa), the garlic (Allium sativa), the onion (Allium cepa) and the tomato Débora variety (Solanum lycopersicum) were acquired in a local supermarket in the city of Piracicaba, State of São Paulo, Brazil.

\subsection{Treatments preparation}

Bean: the grains were left in maceration at the proportion 3:1 (water:bean), in 250-mL Erlenmeyer for 10 hours in distilled water; the water was changed in the proportion 2:1 (water:bean) and the grains were cooked in autoclave at $121^{\circ} \mathrm{C}$ for 10 minutes.

Rice: The grains were cooked for 10 minutes with the proportion 1:2 of rice/distilled water.

Tomato: It was used raw, so it was added after the thermal treatment of the rice and of bean. There were used approximately $230 \mathrm{~g}$ of tomato for each $100 \mathrm{~g}$ of the rice-and-bean mix, after cooking, following the proposed by Fantini et al. (2008). After the addition, it was all homogenized with the aid of a mixer.

Garlic and onion: They were thinly diced and added to the rice while it was cooking. There were used $0.5 \mathrm{~g}$ of garlic and $3 \mathrm{~g}$ of onion for each $10 \mathrm{~g}$ of the rice-and-bean mix (weight before cooking), based on the study of Gautam et al. (2010).

\subsection{Methods}

\subsubsection{Humidity determination}

A gravimetric method was used according to Association of Official Analytical Chemists (2006). The results were expressed in percentages.

\subsubsection{Iron and zinc determination}

The mineral elements were determined in accord with the methodology proposed by Miller (1998): the nitric-perchloric digestion. The samples were placed in flasks for absorbance reading in an Optical Emission with Plasma Inductively Attached spectrophotometer Thermo Scientific iCAP 6300 DUO Series (ICP-OES), at the Laboratory of Environmental Analyses from the department of Soil Sciences of the University of São Paulo-Escola Superior de Agricultura Luiz de Queiroz campus. The wavelengths used were 259.9 and $213.8 \mathrm{~nm}$ for iron and zinc, respectively. The analysis was conducted in triplicate and the results were expressed in $\mathrm{mg} / \mathrm{Kg}$.

\subsubsection{Iron and zinc bioaccessibility}

Cellular cultivation: The human intestine epithelial cells of the Caco-2 lineage (ATCC ${ }^{\circledR} \mathrm{HTB} 37^{\mathrm{mI}}$ ) were cultivated in the cultivation laboratory of Caco-2 cells at the Department of Agroindustry, Food and Nutrition of ESALQ/USP, following the procedures described by Glahn et al. (1998) and Garret et al. (1999). In the experiment, cells were used in the passage $28-31$ and sown at the concentration $2.4 \times 10^{5}$ cells $/ \mathrm{mL}$. The medium used for the culture was DMEM - Dulbecco's Modified Eagle's Medium (D7777;Sigma $\left.{ }^{\circledR}\right)$, which was supplemented with $1 \%$ of L-glutamine, $1 \%$ of non-essential amino acids solution, $1 \%$ of penicillin-streptomycin antibiotic, $0.8 \%$ of fungizone antimycotic, and $15 \%$ of bovine fetal serum (BFS). The flasks were kept in incubator with humidified atmosphere at $5 \%$ of 
$\mathrm{CO}_{2}$ and $95 \%$ of atmospheric air at $37^{\circ} \mathrm{C}$. The plates presented to be confluent after approximately 8-9 days after sowing. The plates T-25 were used for the experimental phase between the $14^{\text {th }}$ and $15^{\text {th }}$ after-confluency.

The in vitro simulation of digestion, including the oral, gastric and intestinal phase followed the procedures described by Garret et al. (1999) and Glahn et al. (2002). Experimental phase: The essays were made in triplicate and besides the treatments the negative control was made (which was used for iron as well as for zinc) as well as the positive control for iron (it was added $0.5 \mathrm{~g}$ of ferrous sulphate and $0.5 \mathrm{~g}$ of ascorbic acid). At the end of the in vitro digestion process, the $12 \mathrm{~mL}$ aliquot was removed from the digested materials that were submitted to centrifugation $\left(1370 \times \mathrm{g} / 45 \mathrm{~min} / 4^{\circ} \mathrm{C}\right)$. The supernatant was collected, filtered by cellulose membranes (Milipore ${ }^{\circledR} 0.22 \mu \mathrm{m}$ of pore) and added to the cell culture. The soluble fraction was diluted in the proportion 1:4 in a basal DMEM ( $\mathrm{pH}$ 6.2) culture medium. The plates were incubated at $37^{\circ} \mathrm{C}$ for two hours. After the incubation period, the DMEM basal medium was added and the flasks remained incubated for more 22 hours. After this period, the DMEM medium was removed from the plates and washes were conducted using $3 \mathrm{~mL}$ of phosphate buffer saline solution (PBS), with pH 7.0. Next, the cells were collected with the aid of a scraper. The treatments were transferred to a Falcon tube of $15 \mathrm{~mL}$ and after they were centrifuged $\left(4^{\circ} \mathrm{C} / 10 \mathrm{~min} / 250 \times \mathrm{g}\right)$. The supernatant was discarded and the cell pellet was frozen at $80{ }^{\circ} \mathrm{C}$. The absorbance of the standards and samples was measured in spectrophotometer at $595 \mathrm{~nm}$.

\subsubsection{Ferritin determination}

The tubes with the cell pellets were defrosted at ambient temperature and there was added $100 \mu \mathrm{L}$ of PBS. The tubes were agitated in vortex for 1 minute, left in ultrasound bath for 15 minutes and agitated again for 1 minute. The ferritin analysis was conducted with ELISA Kit (Phoenix, EK-310-25). The results were expressed in ng of ferritin/mg of protein.

\subsubsection{Zinc determination}

It was made in accord with Vasiluk et al. (2011). To the cell pellet $1 \mathrm{~mL}$ of nitric acid $2 \%$ was added with $4 \mathrm{~mL}$ of deionized water, which remained resting for one night. Following, the absorbance reading was conducted in an Optical Emission with Plasma Inductively Attached spectrophotometer Thermo Scientific iCAP 6300 DUO Series (ICP-OES) in the samples and of the standards with known concentrations of zinc at $0.005 ; 0.01 ; 0.03 ; 0.05 ;$ and $0.1 \mathrm{mg} . \mathrm{L}^{-1}$. The results were expressed in $\mathrm{mg}$ of zinc per $\mathrm{mg}$ of protein. The analysis was conducted at the Laboratory of Environmental Analyses, belonging to the Department of Soil Sciences located in the ESALQ-USP. The results were expressed in $\mathrm{mg}$ of zinc/mg of protein.

\subsection{Statistical analysis}

The experimental design was entirely randomized. The results were submitted to the variancy analysis (ANOVA) and the means compararison was conducted by Tukey test at $5 \%$ of significancy. For all analyses, the statistical pack Statistical Analysis System (1996) was used.

\section{Results and discussion}

The humidity rates in the treatments 2 and 4 were the most elevated (Table 1) and this is due to the presence of tomato in these mixes, since it presents $95 \%$ of water in its composition (Núcleo de Estudos e Pesquisas em Alimentação, 2011).

In the measure of iron bioaccessibility, in order to verify the viability of the experiment, a treatment named positive control was conducted, which was composed by $500 \mathrm{mg}$ of ferrous sulfate $+500 \mathrm{mg}$ of ascorbic acid. The ferrous sulfate is considered effective as positive control since it induces the ferritin synthesis (Vaz-Tostes et al., 2016). The positive control has normally elevated the ferritin rate since it does not present antinutritional factors, which is present in the food. A treatment of negative control was also conducted, which did not contain any sample, only DMEM medium and Caco-2 cells.

Regarding iron total rates, the treatments which contained rice and bean (T1) and the one which contained rice, bean, garlic, and onion (T3) statistically differed from the treatments 2 and 4 (Figure 1). This result was expected since these treatments presented tomato in its mix, suggesting that the iron derived from this fruit caused this increase in the mineral total rate. Tomato presents $0.2 \mathrm{mg}$ of iron per $100 \mathrm{~g}$ in humid base, however this value becomes meaningful when in dry base. This is due to the high water rate present in the tomato.

Even with treatment 2 and 4 presenting superior iron rates in relation with the treatments 1 and 3 , its bioaccessibility did not significantly differ between these treatments, with only the treatment 4 being significantly different (Figure 1). It presented a more elevated ferritin concentration, supposing that the promoters

Table 1. Humidity rate of the treatments in $\% ;(n=3)$.

\begin{tabular}{lc}
\hline \multicolumn{1}{c}{ Treatment } & Mean \pm SD \\
\hline T1 (Rice, bean) & $66.84^{\mathrm{c}} \pm 0.08$ \\
T2 (rice, bean, tomato) & $86.39^{\mathrm{b}} \pm 0.03$ \\
T3 (rice, bean, garlic, onion) & $66.78^{\mathrm{c}} \pm 0.12$ \\
T4 (rice, bean, garlic, onion, tomato) & $86.84^{\mathrm{a}} \pm 0.09$ \\
\hline
\end{tabular}

Means followed by the same letter in the same column did not present significant difference ( $95 \%$ confidence).

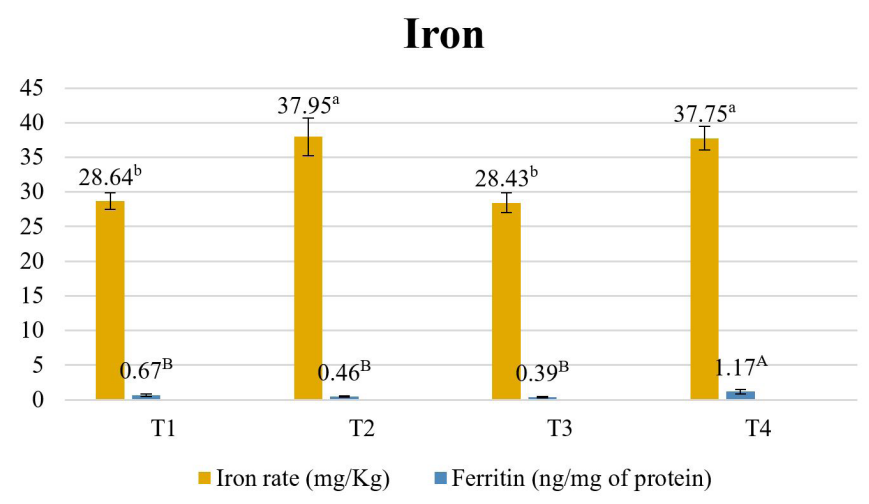

Figure 1. Total rates of iron $(\mathrm{mg} / \mathrm{Kg}$ ) and bioaccessibility of iron (ng of ferritin/mg of protein) of the four treatments (T1: rice, bean; T2: rice, bean, tomato; T3: rice, bean, garlic, onion; T4: rice, bean, garlic, onion, tomato). (a) differs from (b), in the same variable. (A) differs from (B). 
combination (ascorbic acid and cysteine) is promising to elevate the iron absorption. This is different from the study of He et al. (2013), who managed to increase the bioaccessibility with only one promoter added, for the rice already has a natural high rate of cysteine. The work analyzed eleven genotypes of polished rice in the cooked form regarding the bioaccessibility of iron comparing the samples with and without the presence of ascorbic acid. The study used the Caco-2 cell model and the samples which received ascorbic acid present a higher bioaccessibility rate, indicating that the vitamin $\mathrm{C}$ increased the iron absorption. Only two genotypes did not have significant results regarding the bioaccessibility in the presence of ascorbic acid.

In the study of Yun et al. (2004), different doses of vitamin C were added to semi-synthetic meals and the quantity of ferritin formed by the Caco- 2 cells increased, confirming that the ascorbic acid acted as promoter of the iron absorption for the ferritin synthesis. The vitamin C doses were $0 ; 25 ; 50 ; 100 ; 250$; and $500 \mathrm{mg}$. The quantity of ferritin was $16.3 ; 54 ; 74.3 ; 104 ; 226.6$; and $283.9 \mathrm{ng}$ of ferritin/mg of protein, respectively. The increase in the iron rate provoked by the ascorbic acid was also found in the studies of Tetens et al. (Tetens et al., 2005), who proposed six types of diets with addition of many vitamin $C$ levels, three of them with low levels (from 26 to $34 \mathrm{mg}$ ) and three with high levels (from 115 to $123 \mathrm{mg}$ ). An increase of iron rate was observed in those meals which received more elevated vitamin $\mathrm{C}$ doses. However, in another study there were no elevated rates of total iron levels when added with vitamin $\mathrm{C}$, but in the absorbed fraction there was an increase of $1.5 \%$ in fortified oat drinks (Trinidad et al., 2014).

Treatment 3 received garlic and onion because this food contain cysteine, a sulphurated amino acid capable of promoting the bioavailability of some minerals. This treatment had no significant difference in relation to treatment 1 for iron rate, which contained only rice and bean. Similar result was found in the work of Fantini et al. (2008), in which food combinations were made in order to provide the iron increase using tomato and rice as source of ascorbic acid and cysteine, respectively. The iron rate found in the treatment which contained only bean $(17.11 \mathrm{mg} / \mathrm{Kg}$ ) had no significant difference in relation to the one which contained rice as source of cysteine $(17.45 \mathrm{mg} / \mathrm{Kg})$.

Fantini et al. (2008) found higher dialyzable iron rate in the mix which contained tomato and rice along with bean, that is, the two promoters in the same treatment, with no observation of iron increase in the combination that contained only cysteine as promoter, in accord with the results of this work.

Treatments 1 (rice, bean), 2 (rice, bean and tomato) and 3 (rice, bean, garlic, and onion) did not differ between each other in relation to the zinc total rate, while the treatment 4 (rice, bean, garlic, onion, and tomato) differed from the others being the mix which contains the lowest rate of the element. This can be due to the fact that the treatment is the one which contains the lowest quantity of rice and bean, that are the main sources of zinc in the mix.

Many factors can act in the zinc inhibition, like the iron, however only when the molar ratio is higher than 25:1 (Sandström et al., 1985), which do not apply to this study. Phytate and nucleic acids (all the compounds containing phosphorus) reduce the zinc absorption and calcium can also affect negatively when in the presence of phytate (Davies \& Olpin, 1979).

Although the treatment 4 (rice, bean, garlic, onion, tomato) has presented a lower numerical value for zinc rate, there was no significant difference for the concentration of zinc absorbed by the cells among the treatments, suggesting that the total zinc rate do not influence the absorbed quantity, but the components present in the diet, does (Figure 2).

The treatments 1 and 3 showed itself similar regarding the total rate and concentration of absorbed zinc, suggesting that the quantity of garlic and onion was not sufficient for increasing the bioaccessibility of this element, despite having a crescent evidence that diets containing sulphurated amino acids can increase the zinc absorption. Garlic and onion are known for containing these amino acids, the cysteine in particular. In this study we did not prove this improvement, however Gautam et al. (2010) obtained positive results for the increase of bioaccessibility not only of zinc but also of iron. The authors tested two quantities of garlic ( 0.25 and $0.5 \mathrm{~g}$ ) and of onion ( 1.5 and $3 \mathrm{~g}$ ) in different cereals, including rice (that also presents a great rate of cysteine). There was also observed an increase in the bioaccessibility resulting from the addition of both quantities, however it was noted that the highest level (which was the double of the lowest), did not provoke proportional increase, such as for iron and zinc. The authors suggest that this may have occurred due to the positive effect be reached, that is, it came closer to the saturation in the lowest dose.

An already published study evaluated the possible interfering substances in the zinc absorption, such as phytate, polyphenols and ascorbic acid and verified that the ascorbic acid did not influence the zinc absorption, just as stated in this work. Besides that, the study evaluated the characteristics of the zinc absorption by the cells, like kinetics and interpolar linkages and concluded that this is a reliable method for evaluating the bioaccessibility of zinc compared with rats and humans (Sreenivasulu et al., 2008). There are other works comparing the Caco-2 cells method with animals and humans (Kruger et al., 2013; Tako et al., 2009), however it is necessary a wider study about the zinc absorption,

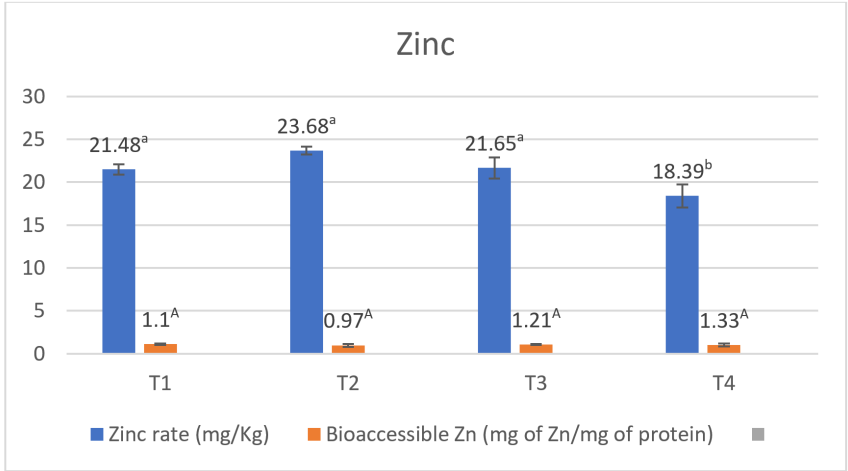

Figure 2. Total zinc rates $(\mathrm{mg} / \mathrm{Kg})$ and bioaccessibility of zinc (mg of zinc/mg of protein) of the four treatments (T1: rice, bean; T2: rice, bean, tomato; T3: rice, bean, garlic, onion; T4: rice, bean, garlic, onion, tomato). (a) differs from (b), in the same variable. There was no significant difference for bioaccessible zinc $(A), p<0,05$. 
possible competition with other minerals and food that can promote its bioaccessibility.

\section{Conclusion}

The ascorbic acid and the cysteine, when together, are more efficient in the mineral absorption, because the treatment which contained rice, bean, garlic, onion, and tomato obtained the best result among the others for as iron as well as for zinc, even being the treatment that initially contained the lowest rate of this last element. That is the importance of evaluating the components of a diet consumed by the Brazilian population.

\section{Acknowledgements}

To the Coordination of Personnel Improvement in Superior Level - Brazil (CAPES) - Financing Code 001.

\section{References}

Ackland, M. L., \& McArdle, H. J. (1990). Significance of extracellular zinc- binding ligands in the uptake of zinc by human fibroblasts. Journal of Cellular Physiology, 145(3), 409-413. http://dx.doi. org/10.1002/jcp.1041450304. PMid:1703164.

Association of Official Analytical Chemists - AOAC. (2006). Official methods of analysis of AOAC International (16th ed.). Arlington: AOAC.

Bobilya, D. J., Briske-Anderson, M., \& Reeves, P. G. (2013). Ligands influence $\mathrm{Zn}$ transport into cultured endothelial cells. Experimental Biology and Medicine, 202(2), 159-166. http://dx.doi.org/10.3181/00379727202-43522. PMid:24326414.

Bouis, H. E., \& Welch, R. M. (2010). Biofortification-a sustainable agricultural strategy for reducing micronutrient malnutrition in the global south. Crop Science, 50(April), S-20-S-32. http://dx.doi. org/10.2135/cropsci2009.09.0531.

Clydesdale, F. M., Ho, C., Lee, C. Y., Mondy, N. I., Shewfelt, R. L., \& Lee, K. (1991). The effects of postharvest treatment and chemical interactions on the bioavailability of ascorbic acid, thiamin, vitamin a, carotenoids, and minerals. Critical Reviews in Food Science and Nutrition, 30(6), 599-638. http://dx.doi.org/10.1080/10408399109527558. PMid:1741953.

Cozzolino, S. M. F. (2012). Biodisponibilidade de nutrientes (4. ed.). Barueri: Manole.

Davies, N. T., \& Olpin, S. E. (1979). Studies on the phytate : zinc molar contents in diets as a determinant of $\mathrm{Zn}$ availability to young rats. British Journal of Nutrition, 41(3), 590-603. http://dx.doi.org/10.1079/ BJN19790074. PMid:572702.

Depar, N., Rajpar, I., Memon, M., Imtiaz, M., \& Zia-Ul-Hassan, S. (2011). Mineral nutrient densities in some domestic and exotic rice genotypes. Pakistan Journal of Agriculture, Agricultural Engineering \& Veterinary Sciences, 27(2), 134-142.

Etcheverry, P., Grusak, M. A., \& Fleige, L. E. (2012). Application of in vitro bioaccessibility and bioavailability methods for calcium, carotenoids, folate, iron, magnesium, polyphenols, zinc, and vitamins B 6, B 12, D, and E. Frontiers in Physiology, 3, 317. http://dx.doi. org/10.3389/fphys.2012.00317. PMid:22934067.

Fantini, A. P., Canniatti-Brazaca, S. G., Souza, M. C., \& Mansi, D. N. (2008). Disponibilidade de ferro em misturas de alimentos com adição de alimentos com alto teor de vitamina C e de cisteína. Food Science and Technology (Campinas), 28(2), 435-439. http://dx.doi. org/10.1590/S0101-20612008000200026.
Fitzgerald, M. A., McCouch, S. R., \& Hall, R. D. (2009). Not just a grain of rice: the quest for quality. Trends in Plant Science, 14(3), 133-139. http://dx.doi.org/10.1016/j.tplants.2008.12.004. PMid:19230745.

Garret, D. A., Failla, M. L., \& Sarama, R. J. (1999). Development of an in vitro digestion method to assess carotenoid bioavailability from meals. Journal of Agricultural and Food Chemistry, 47(10), 4301-4309. http://dx.doi.org/10.1021/jf9903298. PMid:10552806.

Gautam, S., Platel, K., \& Srinivasan, K. (2010). Higher Bioaccessibility of iron and zinc from food grains in the presence of garlic and onion. Journal of Agricultural and Food Chemistry, 58(14), 8426-8429. http://dx.doi.org/10.1021/jf100716t. PMid:20597543.

Glahn, R. P., Lee, O. A., Yeung, A., Goldman, M. I., \& Miller, D. D. (1998). Caco-2 cell ferritin formation predicts nonradiolabeled food iron availability in an in vitro digestion/Caco-2 cell culture model. The Journal of Nutrition, 128(9), 1555-1561. http://dx.doi. org/10.1093/jn/128.9.1555. PMid:9732319.

Glahn, R. P., Wortley, G. M., South, P. K., \& Miller, D. D. (2002). Inhibition of iron uptake by phytic acid, tannic acid, and $\mathrm{ZnCl}$ : Studies using an in vitro digestion/Caco-2 cell model. Journal of Agricultural and Food Chemistry, 50(2), 390-395. http://dx.doi. org/10.1021/jf011046u. PMid:11782213.

Hayat, I., Ahmad, A., Masud, T., Ahmed, A., \& Bashir, S. (2014). Nutritional and health perspectives of beans (Phaseolus vulgaris L.): an overview. Critical Reviews in Food Science and Nutrition, 54(5), 580-592. http://dx.doi.org/10.1080/10408398.2011.596639 . PMid:24261533.

He, W. L., Feng, Y., Wei, Y. Y., Yang, X. E., Shi, C. H., He, Z. L., \& Stoffella, P. J. (2013). Differential iron-bioavailability with relation to nutrient compositions in polished rice among selected Chinese genotypes using Caco-2 cell culture model. International Journal of Food Sciences and Nutrition, 64(7), 822-829. http://dx.doi.org/1 0.3109/09637486.2013.803520. PMid:23796044.

Institute of Medicine - IOM. (2006). Part III: vitamins and mineralspotassium. In J. J. Otten, J. P. Hellwig \& L. D. Meyers (Eds.), Dietary reference intakes: the essential guide to nutrient requirements (pp. 370-380). Washington: The National Academies Press. Retrieved from www.iom.edu

Jacob, J. K., Tiwari, K., Correa-Betanzo, J., Misran, A., Chandrasekaran, R., \& Paliyath, G. (2012). Biochemical basis for functional ingredient design from fruits. Annual Review of Food Science and Technology, 3(1), 79-104. http://dx.doi.org/10.1146/annurev-food-022811-101127. PMid:22224553.

Khouzam, R. B., Pohl, P., \& Lobinski, R. (2011). Bioaccessibility of essential elements from white cheese, bread, fruit and vegetables. Talanta, 86(1), 425-428. http://dx.doi.org/10.1016/j.talanta.2011.08.049. PMid:22063561.

Kruger, J., Taylor, J. R. N., Du, X., Moura, F. F., Lönnerdal, B., \& Oelofse, A. (2013). Effect of phytate reduction of sorghum, through genetic modification, on iron and zinc availability as assessed by an in vitro dialysability bioaccessibility assay, Caco-2 cell uptake assay, and suckling rat pup absorption model. Food Chemistry, 141(2), 1019-1025. http://dx.doi.org/10.1016/j.foodchem.2013.01.105. PMid:23790881.

Miller, R. O. (1998). Handbook of reference methods for plant analysis. In Y. P. Kalra (Ed.), Handbook of reference methods for plant analysis (vol. 38, pp. 57-62). Washington: CRC Press. https://doi.org/10.2135/ cropsci1998.0011183x003800060050x.

Minguita, A. P. D. S., Carvalho, J. L. V., Oliveira, E. M. M., \& Galdeano, M. C. (2015). Production and characterization of pasta from biofortified foods: wheat flour, polished rice flour and whole bean 
flour. Ciência Rural, 45(10), 1895-1901. http://dx.doi.org/10.1590/01038478 cr20140491.

Moura, N., \& Canniatti-Brazaca, S. (2006). Avaliação da disponibilidade de ferro de feijão comum. Food Science and Technology (Campinas), 26(2), 270-276. http://dx.doi.org/10.1016/j.foodchem.2006.06.025.

Núcleo de Estudos e Pesquisas em Alimentação - NEPA. (2011). Brazilian food composition table. Campinas: UNICAMP.

Paripatananont, T., \& Lovell, R. T. (1995). Chelated zinc reduces the dietary zinc requirement of channel catfish, Ictalurus punctatus. Aquaculture, 133(1), 73-82. http://dx.doi.org/10.1016/00448486(94)00404-C.

Rehman, H., Aziz, T., Farooq, M., Wakeel, A., \& Rengel, Z. (2012). Zinc nutrition in rice production systems: a review. Plant and Soil, 361(1-2), 203-226. http://dx.doi.org/10.1007/s11104-012-1346-9.

Rein, M. J., Renouf, M., Cruz-Hernandez, C., Actis-Goretta, L., Thakkar, S. K., \& Silva Pinto, M. (2013). Bioavailability of bioactive food compounds: a challenging journey to bioefficacy. British Journal of Clinical Pharmacology, 75(3), 588-602. http://dx.doi.org/10.1111/ j.1365-2125.2012.04425.x. PMid:22897361.

Sandström, B., Davidsson, L., Cederblad, A., \& Lonnerdal, B. (1985). Oral iron, dietary ligands and zinc absorption. The Journal of Nutrition, 115(3), 411-414. http://dx.doi.org/10.1093/jn/115.3.411. PMid:3973750.

Shimelis, E. A., \& Rakshit, S. K. (2005). Proximate composition and physico-chemical properties of improved dry bean (Phaseolus vulgaris L.) varieties grown in Ethiopia. Lebensmittel-Wissenschaft + Technologie, 38(4), 331-338. http://dx.doi.org/10.1016/j.lwt.2004.07.002.

Sreenivasulu, K., Raghu, P., Ravinder, P., \& Nair, K. M. (2008). Effect of dietary ligands and food matrices on zinc uptake in Caco-2 cells: Implications in assessing zinc bioavailability. Journal of Agricultural and Food Chemistry, 56(22), 10967-10972. http://dx.doi.org/10.1021/ jf802060q. PMid:18947232.

Statistical Analysis System. (1996). Sas/Stat 9.1 ${ }^{\circledR}$ user's guide (6th ed.) Cary: S.A.S. Stat.

Tako, E., Glahn, R. P., Laparra, J. M., Welch, R. M., Lei, X., Kelly, J. D., Rutzke, M. A., \& Miller, D. D. (2009). Iron and zinc bioavailabilities to pigs from red and white beans (Phaseolus vulgaris L.) are similar. Journal of Agricultural and Food Chemistry, 57(8), 3134-3140. http:// dx.doi.org/10.1021/jf803647m. PMid:19368350.
Tetens, I., Larsen, T. M., Kristensen, M. B., Hels, O., Jensen, M., Morberg, C. M., Thomsen, A. D., Højgaard, L., \& Henriksen, M. (2005). The importance of dietary composition for efficacy of iron absorption measured in a whole diet that includes rye bread fortified with ferrous fumerate: a radioisotope study in young women. British Journal of Nutrition, 94(5), 720-726. http://dx.doi.org/10.1079/ BJN20051556. PMid:16277774.

Trinidad, T. P., Kurilich, A. C., Mallillin, A. C., Walcyzk, T., Sagum, R. S., Singh, N. N., Harjani, Y., de Leon, M. P., Capanzana, M. V., \& Fletcher, J. (2014). Iron absorption from NaFeEDTA-fortified oat beverages with or without added vitamin C. International Journal of Food Sciences and Nutrition, 65(1), 124-128. http://dx.doi.org/1 0.3109/09637486.2013.836739. PMid:24059906.

Vasiluk, L., Dutton, M. D., \& Hale, B. (2011). In vitro estimates of bioaccessible nickel in field-contaminated soils, and comparison with in vivo measurement of bioavailability and identification of mineralogy. The Science of the Total Environment, 409(14), 2700-2706. http://dx.doi.org/10.1016/j.scitotenv.2011.03.035. PMid:21531008.

Vaz-Tostes, M., Verediano, T. A., Mejia, E. G., \& Costa, N. M. B. (2016). Evaluation of iron and zinc bioavailability of beans targeted for biofortification using in vitro and in vivo models and their effect on the nutritional status of preschool children. Journal of the Science of Food and Agriculture, 96(4), 1326-1332. http://dx.doi.org/10.1002/ jsfa.7226. PMid:25899136.

Wapnir, R. A., Garcia-Aranda, J. A., Mevorach, D. E. K., \& Lifshitz, F. (1985). Differential absorption of zinc and low-molecular-weight ligands in the rat gut in protein-energy malnutrition. The Journal of Nutrition, 115(7), 900-908. http://dx.doi.org/10.1093/jn/115.7.900. PMid:3925095.

Wapnir, R. A., Khani, D. E., Bayne, M. A., \& Lifshitz, F. (1983). Absorption of zinc by the rat ileum: effects of histidine and other low-molecularweight ligands. The Journal of Nutrition, 113(7), 1346-1354. http:// dx.doi.org/10.1093/jn/113.7.1346. PMid:6864333.

Yun, S., Habicht, J.-P., Miller, D. D., \& Glahn, R. P. (2004). An in vitro digestion/caco-2 cell culture system accurately predicts the effects of ascorbic acid and polyphenolic compounds on iron bioavailability in humans. The Journal of Nutrition, 134(10), 2717-2721. http:// dx.doi.org/10.1093/jn/134.10.2717. PMid:15465772. 